\title{
部分骨組の履歴ループ形状が建物の安定性と最大応答変形に及ぼす影響 \\ HYSTERESIS LOOP EFFECTS ON STABILITY AND MAXIMUM DRIFT OF STRUCTURES
}

\author{
田川浩 之*，グレゴリー マックレイ**，ローラ ローズ*** \\ Hiroyuki TAGAWA, Gregory MACRAE and Laura LOWES
}

\begin{abstract}
The influence of hysteretic loops with negative post-yield tangent stiffness and multi-yield characteristics on seismic response of single-degree-of-freedom (SDOF) and multi-degree-of-freedom (MDOF) structures is investigated in this study. The SDOF models, MDOF shear-beam models, and MDOF coupled shear-flexural-beam models with various structural parameters are analyzed for a number of ground motions to identify the trend of structural response. Major findings are 1) SDOF and MDOF shear-beam model have a large probability of crawling collapse once the structure exhibits a negative post-yield tangent stiffness, 2) the change of hysteretic loop with negative slope to multi-yield loop is effective to reduce the maximum story drift particularly for MDOF shear-beam model, and 3) the addition of flexural-beam to the shear-beam is very effective to reduce the maximum story drift and drift concentrations, which diminishes the multi-yield hysteretic loop effects.
\end{abstract}

Keywords: Coupled shear-flexural-beam model, Hysteretic loop shape, Negative tangent stiffness, Dynamic stability 混合せん断+曲げ棒モデル、履歴復元カループ形状、負の接線剛性、動的安定性

1. はじめに

兵庫県南部地震では多数の建築構造物が崩填した。建物崩填の防 止は、構造研究者及び設計者の第一義の目的である。近年、建築基 淮 ${ }^{1), 2)}$ に取り入られた性能評価型の耐展設計法に於いても、耐震設計 および補強の段階で建物に付与すべき重要な性能指標の 1 つである。 建物崩壊を防ぐには、(1) 建物の不安定な挙動の開始点を予測し、(2) 多少の不安定挙動を許容する場合、それによる建物応答の增加を正 しく評価し、(3) 不安定举動を低減する方法を取り入れる、ことが必 要である。不安定举動を起こすような大地震に対する建物の举動は、 地祳動の特性や建物の固有周期のみならず、塑性域における建物特 性(建物要素の履歴復元カループ形状、特に塑性時での接線剛性)に も大きく依存する.

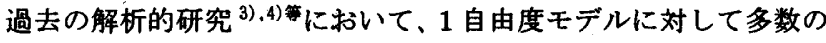
動的非線形解析が行われ、モデルが降伏後に材料劣化、もしくは $P-\Delta$ 効果により負勾配を呈するようになると、建物変形量が 1 方向に偏 り不安定な举動を起こし、さらには崩壊に至る危険性が著しく大き くなることが明らかになっている。しかしながら、実験等で得られ る粠造要素の負の接線剛性が建物全体の挙動に及ぼす影響について は今までのところ必ずしも明確化されているとはいえない．

負勾配の履歷復元力特性を改良して第一降伏点を低下させるかわ りに正勾配に対応する変形領域を增加させ原点指向型の復元力特性
を持たせることは、建物の地震時応答量を低减させる可能性がある。 図 1 に負勾配をもつ Bilinear モデルとそれを改良した並列結合型の Tri-linear モデル ${ }^{5)}$ をしている。Bilinear モデルは Tri-linear モデル よりも高い降伏強度をもつため、強度の点では特に塑性率がごく小 さい領域において小さな最大忘答変形を示すと考えられる。ところ が、Bilinear モデルは Tri-linear モデルよりも小さな変形伈答量で負 の勾配に入る。従って、ある程度塑性率が大きくなった時に大きな 最大忍答変形を示すと考えられる ${ }^{6)}$ 。エネルギー論の観点からは、 図 1(a)に示されるように Bilinear モデルの方が Tri-linear モデルより も静的崩填点に至るまでのエネルギー吸収量は大きくなる。また図 1(b)に示されるように1サイクルにおける構造物が吸収するエネル ギー量(ループ面積で表される)も Bilinear モデルの方が Tri-linear モ デルよりも大きくなる。しかしながら、この多段階降伏ループの地 震時における動的効果について多自由度系の構造モデルに対しては 筆者の知る限りでは過去に研究がなされていない。

本論文の研究目的は、(1)1 自由度モデルにおいて、降伏後の負勾 配、ならびに負勾配を含む多段階降伏型の履歴性状が最大応答変形 量にどのような影響を及ぼすかを明らかにすることである。次いで (2)多自由度せん断型モデルに対しては、各層の降伏後の負勾配、な らびに負勾配を含む多段階降伏型の履歷性状が層閒最大応答変形量 にどのような影響を及ぼすかを調べる。さらには、(3)建物全体を貫
* 東京工業大学都市地震工学センター $\mathrm{COE}$ 研究員・Ph. D.

***カタンベリ一大学土木工学科 準教授・Ph. D .

*** ワシントン大学土木工学科 助教授. Ph. D.
Post-Doctoral Research Fellow, CUEE, Tokyo Institute of Technology, Ph. D. Assoc. Prof., Dept. of Civil Engineering, Univ. of Canterbury, Ph. D. Assistant Prof., Dept. of Civil Engineering, Univ. of Washington, Ph. D. 
く曲げ棒を加えた場合、各層の降伏後の負勾配、ならびに負勾配を 含む多段階降伏型の履歴性状は、層間最大応答変形量にどのような 影繁を及ぼすかを、非線形動的解析を通して明らかにする。

\section{1 自由度系モテルの地震時举胹}

\section{1 負勾四の効果}

はじめに降伏後の接線㣚性、特に負勾配の建物応答に対する影嘕 を評価するために 1 自由度系モデルに対して多数の動的解析を行っ た。図 2 に示す 1 自由度系 Bilinear モデルにおいて降伏後の接線㣚 性率 $(r-\theta)$ を1.0(弾性)加負の值まで小刻みに変えて最大応答変形量 を求めた。固有周期は 1.285 秒、粘性減衰率は $2 \%$ に設定した。固有 周期の值は、後の解析結果と比较するため、9階建ての鉄骨建物を想 定しIBC(2003) に) たする固有周期の推定式により求めた。 SAC(1997) $)^{8)}$ で用いられた断層近傍型の20個の Strike Normal(SN)波と 20個の Strike Parallel(SP)波の地屡波を用いた。図3にそれらの加速度 応答スペクトルを示す。モデルの降伏強度は各々の地屡波に対して 強度低減保数 $R$ が4となるように設定した。

各々の接線剛性率 $(r-\theta)$ に対して、絽り返し時には式(1)で表される

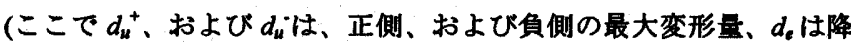
伏時の変形量)上うな最大塑性変形量の最大弾性変形量に対する比 率( $C_{\mu}$ sDOF 所謂、塑性変形增加保数)を20個の SN 波に対して図 4(a) に、20個のSP 波に対して図 4(b)に示寸。図4(a)より20個の SN 波に 対してMedian(50 間は、最大弾性変形量よりやや大きくなる。つまり、 $C_{\mu}^{S D O P}=1$ で 表される変位一定則(EDM)は、少し危険側の予测となる。一方、図 4(b)より20個の SP 波に対して Medianの值は、降伏後の接線㣚性率 が正の間は、最大弾性変形量より小さくなる。これは、SN 波には Pulseの特性が含まれており、これが一方向への塑性変形を促すから で、この傾向は短周期の建物に対して特に観察される ${ }^{10)}$ 。 SN 波、 および SP 波に対しても、降伏後の接線㣚性率が負になると最大応 答変形量は著しく增大する。これは、負の接線剛性に対応する応答 は一般に指数関数的に增加するからで、過去の研究結果 ${ }^{3)}$.4) と一致 する。84 ${ }^{\text {h }}$ Percentile ${ }^{9)}$ の值は、式(2)で表される一方向载荷時での最 大変形量までの弾性時と塑性時における吸収エネルギーが等しいと 仮定して得られたエネルギー一定則(EEM)の曲線にほぼ一致する。

$$
\begin{aligned}
& C_{\mu}^{S D O F}=\frac{\max \left(d_{u}^{+}, d_{u}^{-}\right)}{d_{e}} \\
& C_{\mu}^{S D O F}(E E M)=\frac{(r-\theta)-1+\sqrt{1+R^{2}(r-\theta)-(r-\theta)}}{R(r-\theta)}
\end{aligned}
$$

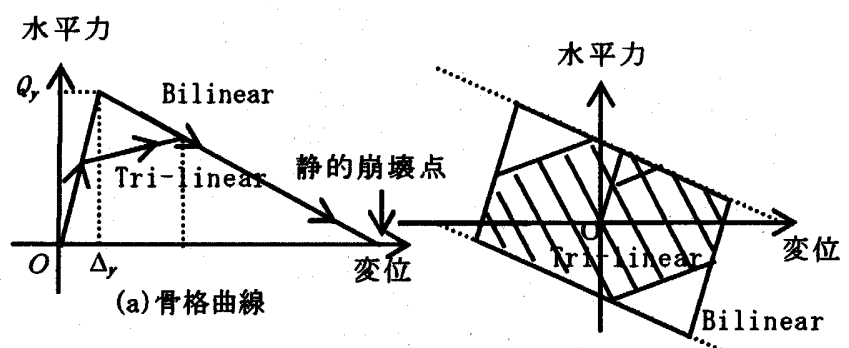

(b) 履歴曲線ループ・....

図 1 Bilinear、Tri-linear の履歴復元力特性のモデル

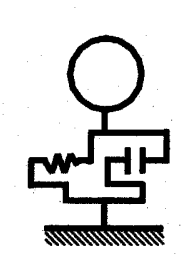

(a) SDOF モデル

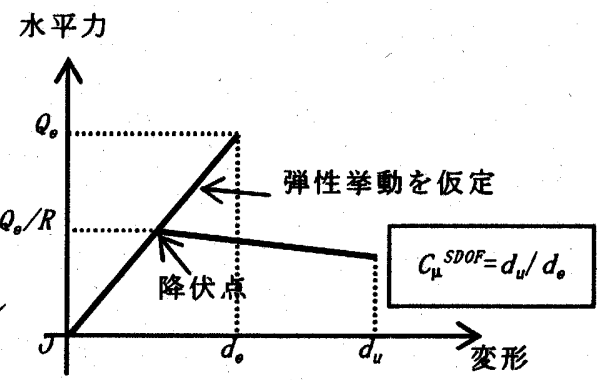

(b)骨格曲線

図 21 自由度系 Bilinear モデル

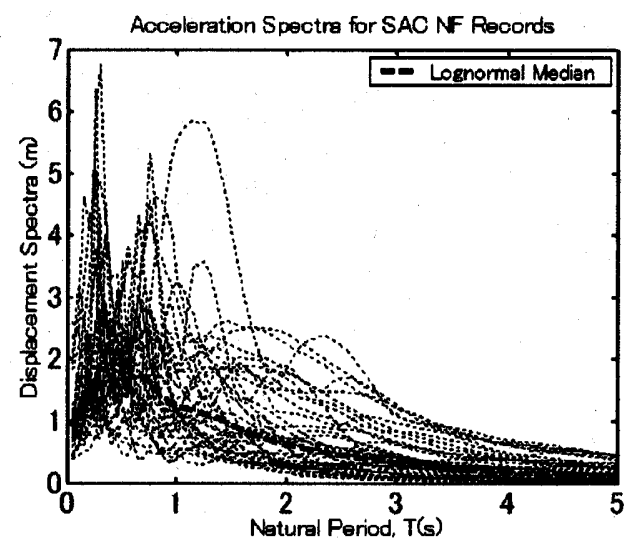

図 3 SAC 地㫳動の加速度応答スペクトル

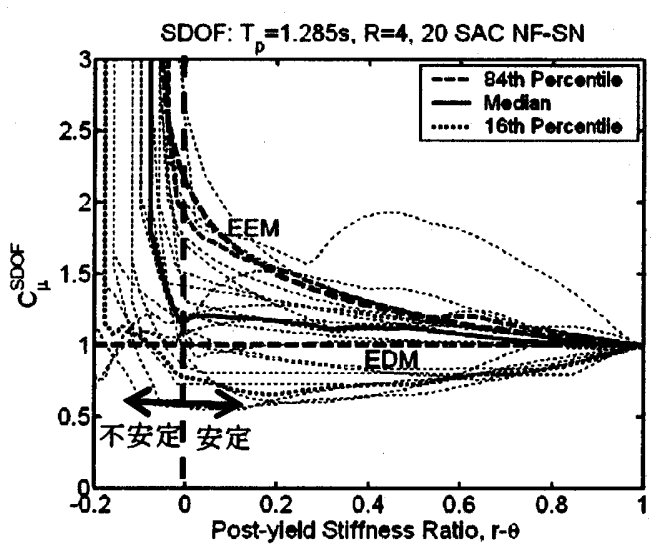

(a) SN 成分に対する最大変形応答

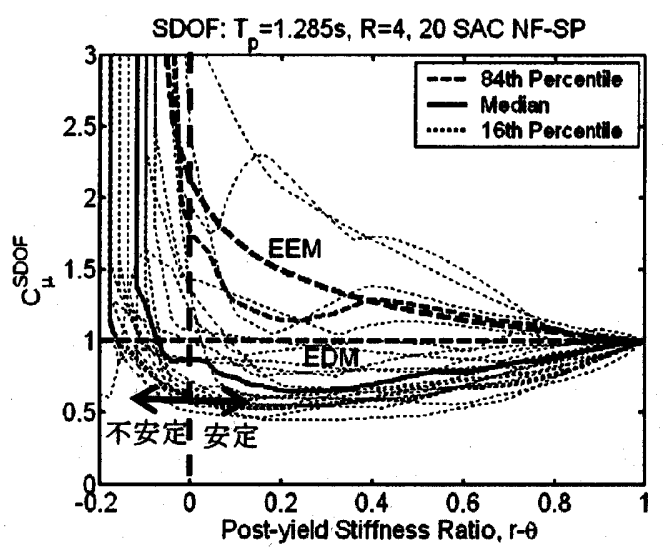

(b) SP 成分に対する最大変形匛答

图 4 様々の塑性時接線剛性をもつSDOF モデルの最大変形応答 


\section{2 多段陼降伏の効果}

2.1 において、1 自由度系の建物は降伏後に負の接線㣚性をもつ と、応答が著しく增加する可能性が大きくなることが分かった。そ こでその 1 つの改善案として Bilinear 型の履歴を Tri-linear 型にかえ て動的解析を行い、1 自由度系における多段階降伏の効果を調へた。 1 自由度系 Tri-linear モデルを図 5(a)に示し、それらの1 方向の層 間変位一荷重曲線を図 $5(\mathrm{~b})$ に示す。この研究では、図 $5(\mathrm{~b})$ に示す ように、Tri-linear モデルの曲線は、折れ曲がり部分(第二分枝)以外 は Bilinear モデルと同じと設定し、図 6(a)に示すように降伏強度低 诚保数を $\alpha_{t r t}=0.25 、 0.5 、 0.75$ 、及び、1.0(Bilinear)とし、また、図 6(b) に示すように最大耐力に相当する変形量の增加俰数を $\beta_{t n}=$ 1(Bilinear)，2，3，4，及ひ、、と設定した。ここでは、Bilinearにお

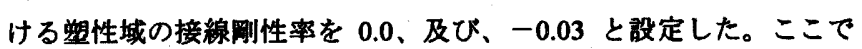
は、 $\beta_{t n}=1$ (Bilinear), 2，3，4，及び、5について述べる。

まず、SAC(1997) $)^{8)}$ の NF05 の地震動を用い徐々に地展動の強さを 增加させ、最大変形応答を求める、所謂 Incremental Dynamic Analysis(IDA)解析 ${ }^{9)}$ を行い、様々の地展動強さに対する多段陼降伏 効果を評価した。元となる Bilinear モデルの降伏強度を強度低減俰 数 R(弾性举動を仮定したときの強度に対する実際の降伏強度の比) が4となるように設定した。その結果を図 7 に示す。 $R$ が 3 までは、 Bilinear モデルも Tri-linear モデルもほぼ同じ最大変形応答を示す。 ところが、Rが 4 を超えるようになると、的什值が増えるに従って、 同じ大きさの地展動強さに対して最大変形応答が小さくなり、また、 大きな地震動の強さで崩壊に至ることが分かる。

40 個の SAC(1997) $)^{8)}$ の NF 地震波に対する、 $R$ が 4 の時の Bilinear 及び Tri-linear モデルにおける $C_{\mu}^{\text {SDOF }}$ を図 8、またそれらの Median の值を表 1 で比較する。Bilinear モデルの塑性域の接線剛性率を 0.0 に設定した時、Tri-linear モデルは、Bilinear よりも僅かに小さな最

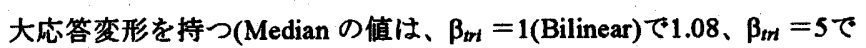
0.93)。しかし、塑性域の接線剛性率を-0.03に設定した時は、Tri-linear モデルは、Bilinear モデルよりも小さな最大変形态答を持つことが分 かる(Median の值は、 $\beta_{t r t}=1$ (Bilinear)で1.18、 $\beta_{t r t}=5$ で0.91)。このこ とは、塑性域の接線剛性が特に負になった時に特に、多段階降伏の 効果が表れたことを示すが、この効果はあまり顕著ではない。 水平力
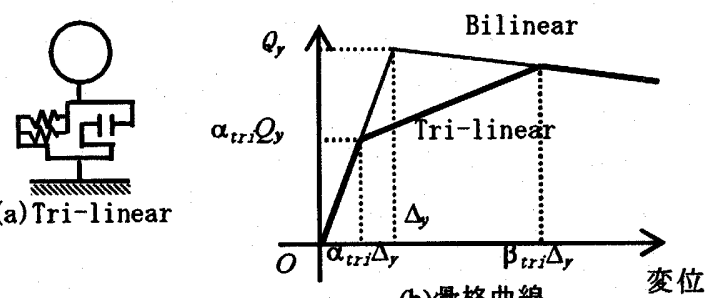

(b)骨格曲線

図 51 自由度系 Tri-linear モデル

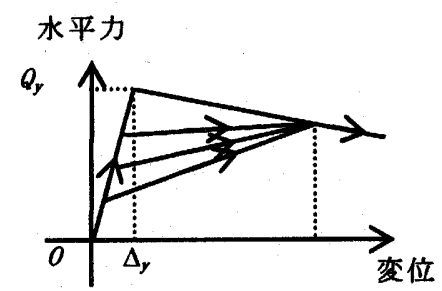

(a) 第一降伏点の違い

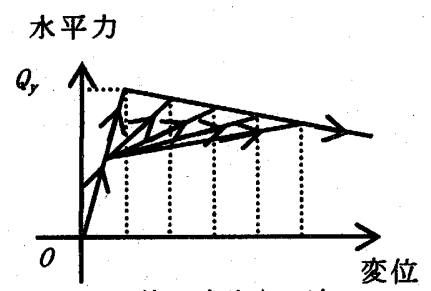

(b) 第二降伏点の違い

図 6 Tri-linear モデルのパラメーター

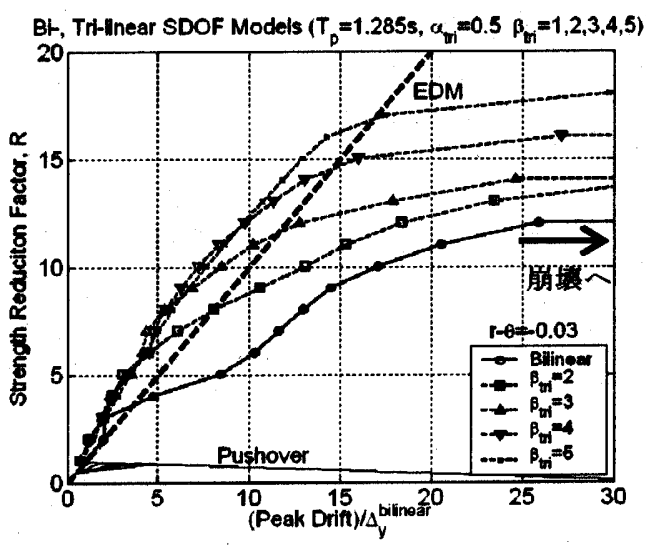

図 7 多段階降伏ループをもった SDOF の最大变形応答

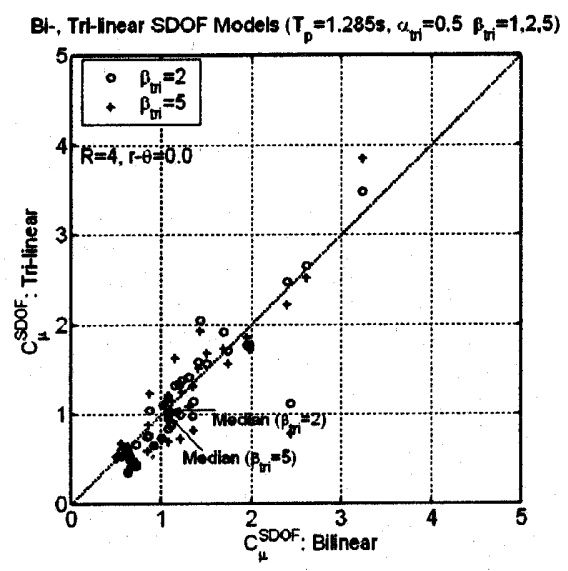

(a) $C_{\mu}{ }^{S D O r}$ for $r-\theta=0.0$

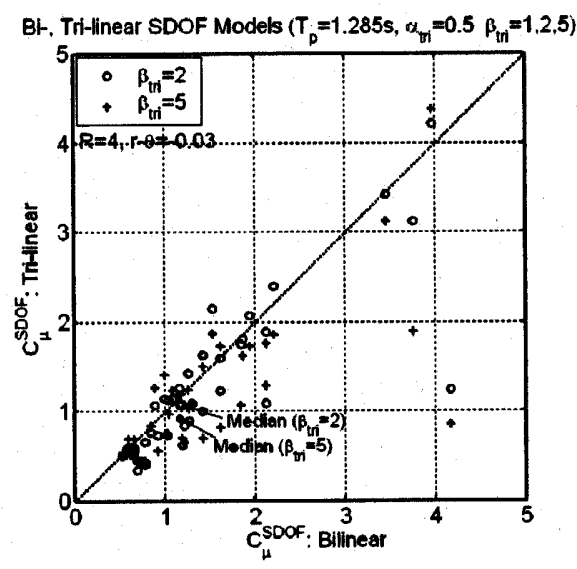

(b) $C_{\mu}{ }^{\text {SDOF }}$ for $r-\theta=-0.03$

因 81 自由度系Bilinear、Tri-linear モデルの動的応答

表1 1 自由度系モデルにおける多段階降伏勃果 $\left(C_{\mu}^{\text {sDOF }}:\right.$ Median)

\begin{tabular}{|c|c|c|c|}
\hline$\beta_{b t}$ & $(\mathrm{r}-\theta)=0.03$ & $(\mathrm{r}-\theta)=0.00$ & $(\mathrm{r}-\theta)=-0.03$ \\
\hline \hline 1 (bilinear) & 1.02 & 1.08 & 1.18 \\
\hline 2 (tri-linear) & 1.00 & 1.02 & 1.08 \\
\hline 5 (tri-linear) & 0.92 & 0.93 & 0.91 \\
\hline
\end{tabular}




\section{3. 多自由度系せん断接モデルの地震時举動}

\section{1 多自由度系せん断棒モデル}

実際の建物は多層であることが多く構造設計において多自由度系 せん断棒モデルが頻繁に用いられてきた。図 9 に示されるせん断棒 モデルの剛性行列式は、式(3)で表され带状となる。ここで、 $k_{1}$ は、 $i$ 層におけるバネ保数である。この形式の剛性行列では、式(4)に示さ れる特性をもちにこで只は $n$ 次モードの固有值)、この式が示すよ うにバネ要素が負の接線剛性をもつ層の数と剛性行列の負となる固 有值の数が一致する ${ }^{10)}$ 。

$$
\left[K_{s}\right]=\left[\begin{array}{ccccc}
k_{1}+k_{2} & -k_{2} & 0 & \cdots & 0 \\
-k_{2} & k_{2}+k_{3} & \ddots & \ddots & \vdots \\
0 & \ddots & \ddots & \ddots & 0 \\
\vdots & \ddots & \ddots & k_{n-1}+k_{n} & -k_{n} \\
0 & \cdots & 0 & -k_{n} & k_{n}
\end{array}\right]
$$

$k_{1} k_{2} k_{3} \cdots k_{n}=\Omega_{1} \Omega_{2} \Omega_{3} \cdots \Omega_{n}$

本研究で用いられたモデルは、IBC(2003) $)^{8)} に$ 定められる層せん断 カに対して全層において層間変形角が一定となるように、また、固 有周期が 1.285 秒となるように、式(5)、(6)で表される式 ${ }^{10)}$ を用いて、 せん断棒の水平バネの剛性を定めた。ここで, SDA は層閒変形角、 $T$ は固有周期、 $F_{i}$ は $i$ 階に加える設計水平外力、 $h_{i}$ は $i$ 階の高さ、 $m_{i}$ は $i$ 階の犋量、 $N$ は階数、 $k_{i}$ は $i$ 階のせん断バネのバネ定数である。

$$
\begin{gathered}
S D A=\frac{T^{2}}{4 \pi^{2}} \cdot \frac{\sum_{i=1}^{N}\left(F_{i} h_{i}\right)}{\sum_{i=1}^{N}\left(m_{i} h_{i}^{2}\right)} \\
k_{i}=\frac{\sum_{n=i}^{N} F_{n}}{S D A \cdot h_{i}}
\end{gathered}
$$

\section{2 負勾眍の効果}

9 自由度系 Bilinear せん断棒モデルにおいて、各層における接線用 性率を 1.0 (弾性)から負の值まで小刻みに変えて各層の最大応答変 形量を求めた。ここでは、全層における質量、および接線剛性率は 一定値に設定した。動的解析には、 $\operatorname{SAC}(1997)^{8)}$ の断層近傍型の40個 の地展波を用い、各層のせん断バネの降伏強度は、各々の地展波に 対して各層の強度低減倸数 $\mathrm{R}$ が4となるように設定した。式(7)で定 義されるように、各層の接線㣚性率に対する、各層の最大応答変形 量の、弾性応答を仮定した時の各層の最大応答変形量に対する比率 $\left(C_{\mu, \text { story }}{ }^{M D O F}\right)$ の最大值を図 $10(\mathrm{a})$ に、式(8)で定義される変形集中率 (DCF)を図 $10(\mathrm{~b})$ に示す。ここで、RDA $A_{\text {inelastic }}^{\text {max }}$ は、建物最上部にお ける最大変位を建物高さで標準化したものである。

$$
\begin{aligned}
& C_{\mu, \text { story }}^{M D O F}=\max \left(\frac{d_{u}^{\text {story }}}{d_{e}^{\text {story }}}\right)=\max \left(\frac{S D A_{\text {inelastic }}^{\max }}{S D A_{\text {elastic }}^{\max }}\right) \\
& D C F=\max \left(\frac{S D A_{\text {inelastic }}^{\max }}{R D A_{\text {inelastic }}^{\max }}\right)
\end{aligned}
$$

図 10 より、接線剛性率が 0.2 以上の時は、 $C_{\text {1.stony }}{ }^{\text {MDOF }}$ はほぼ一定で 変位一定則がほぼ成り立つが、接線㣚性率が，0に近つくと、 $C_{\mu, \text { rory }}{ }^{M D O P} 、 D C F$ は增加し、負になるとそれらは著しく增大する。隶 2 で $C_{\mu, \text { story }}{ }^{M D O R}$ を同じ固有周期、接線剛性率を持つ 1 自由度モデルの $C_{\mu}^{\text {SDO }}$ と比較する。接線剛性率が 0 に近づくと、多自由度せん断棒 モデルでは特定層に変形集中が起こるため、同じ接線㣚性率に対し ても、 $C_{\mu, \text { sorg }}{ }^{M D O R}$ は、 $C_{\mu}^{\text {SDOF }}$ よりも大きくなることが分かる。

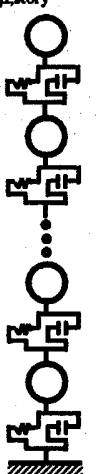

(a)せん断棒モデル

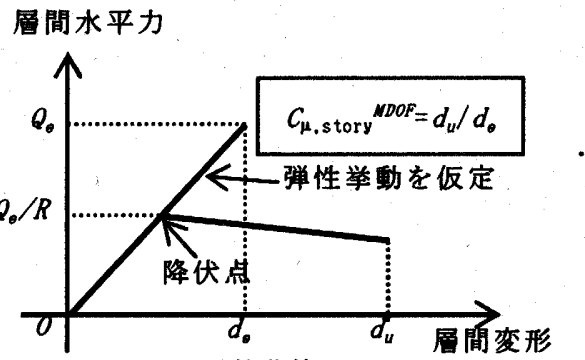

(b)骨格曲線
図 9 多自由度系Bilinear せん断棒モデル 9-story Shear-beam: $T_{p}=1.285 \mathrm{~s}, R=4,40$ SAC NF records

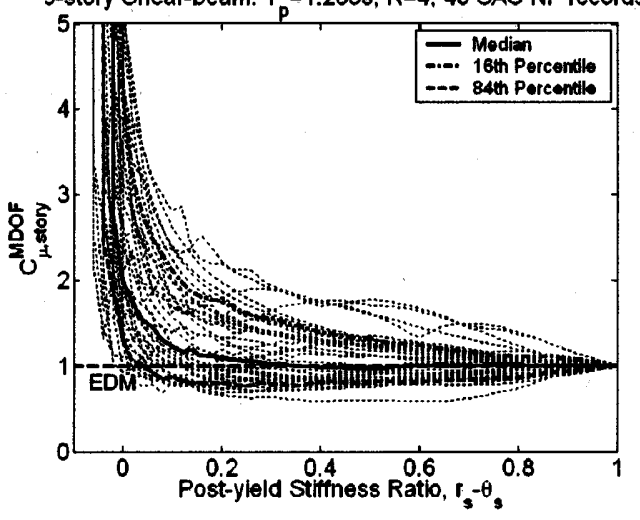

(a) $C_{\mu, \text { story }}{ }^{M D O r}$

9-story Shear-beam: $T_{p}=1.285 \mathrm{~s}, R=4,40 \mathrm{SAC} N \mathrm{~N}$

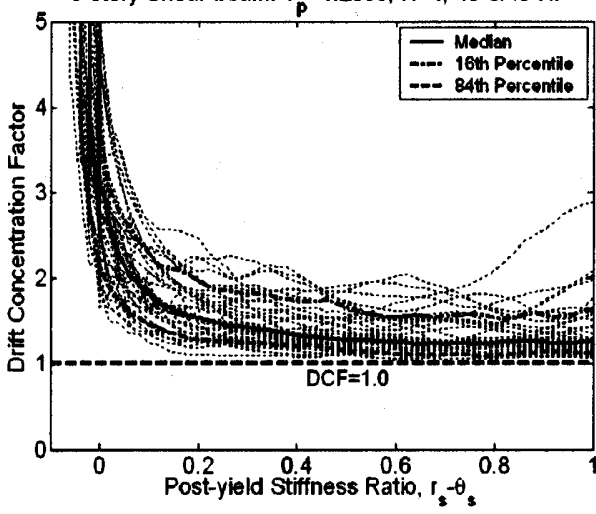

(b) DCF

図 109 自由度系せん断棒 Bilinear モデルの動的応答

表 2 多自由度系モデルにおける $C_{\mu, \text { tory }}{ }^{M D O P}$ と $C_{\mu}^{S D O F}$ の比較

\begin{tabular}{|c|c|c|c|c|c|c|}
\hline$\left(r_{s}-\theta_{3}\right)$ & 0.0 & 0.2 & 0.4 & 0.6 & 0.8 & 1 \\
\hline \hline$C_{\mu, \text { story }}^{\text {MDOF }}$ & 2.00 & 1.08 & 0.99 & 1.01 & 1.01 & 1.00 \\
\hline$C_{\mu}^{\text {SDOF }}$ & 1.08 & 0.90 & 0.84 & 0.87 & 0.98 & 1.00 \\
\hline DCF & 2.74 & 1.54 & 1.34 & 1.26 & 1.25 & 1.27 \\
\hline
\end{tabular}




\section{3 多段階降伏の効果}

3.2 において、Bilinear 型せん断棒モデルはある層において降伏後 に負の接線剛性をもつと、層間変形量が著しく增加することが分か った。そこでその 1 つの改善宋として Bilinear 型の雇歴を Tri-linear 型にかえて動的解析を行い、多自由度系せん断棒モデルにおける多 段階降伏の効果を調べた。多自由度系 Tri-linear せん断棒モデルを図 11(a)に示す。また、それらのモデルの 1 方向の層間変位一何重曲 線モデルは図 11(b)とする。本研究では、 $\alpha_{t r t}=0.5 、 \beta_{t r t}=1,2,3$, 4, 5 と仮定し、モデルは9点とし固有周期を1. $285 \mathrm{~s}$ とした。動的 解析には、これまでの解析と同じく、SAC $(1997)^{8)}$ の断層近傍型の40 個の地震波を用い、元となる Bilinear モデルの各層の降伏強度は強 度低減係数(弾性举動を仮定したときの強度に対する実際の降伏強 度の比)が4となるように設定した。Bilinearにおける各層の塑性時の

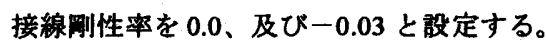

まず、2.2で 1 自由度系モデルで行ったように多自由度系せん断 棒モデルに対しても IDA 解析 ${ }^{9)}$ を行い、様々の地震動强さに対する 多段階降伏効果を評価した。その結果を図 12 に示す。図より各層の 強度低減係数 $R_{s}$ が 5 になると、Bilinear モデルは崩壊する。ところ が Tri-linear では、R $R_{s}$ が 10 より大きくなると崩填するものの、層間 最大変位応答は Bilinear より小さい。

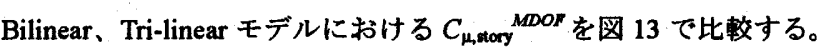
また、それらの Median の值を表 3 に示す。括弧の中の数字は、周 期、強度低減保数、および塑性時の㣚性率が等しい、等価な 1 質点 モデルに対する $C_{\mu}^{\text {SDOF }}$ を示している。塑性時の接線剛性率が 0.0 、 及び-0.03 の時、Tri-linear モデルは、Bilinear モデルよりもかなり小 さな最大変形応答を持っことが分かる。Medianの值は、塑性時の接 線剛性率が 0.0 の時、 $\beta_{t r i}=1$ (Bilinear)で2.05、 $\beta_{t r i}=5$ で1.25、-0.03の 時、 $\beta_{t r i}=1$ (Bilinear)で4.20、 $\beta_{t r i}=5 て ゙ 1.31$ となる。また、等価な 1 自 由度系モデルと比較して、多段階降伏による最大変形応答の低減効 果は大きくなることが分かる。これは、多自由度系ではある特定層 に変形が集中し、その層において多段階降伏の効果が強く表れるか らであると考えられる。
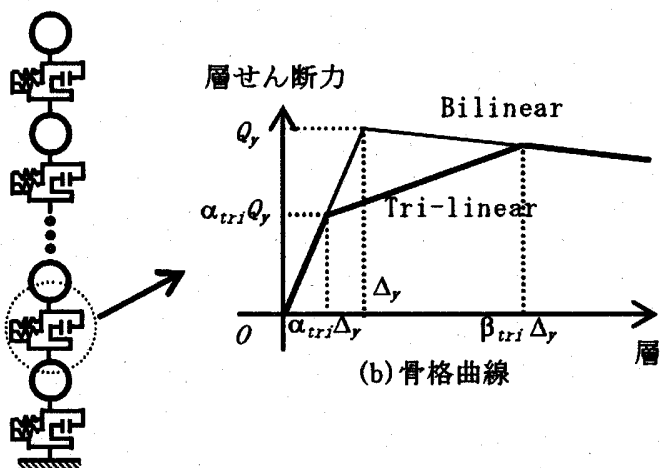

(b) 骨格曲線

(a) Tri-linear

図 11 多自由度系 Bilinear、Tri-linear せん断棒モデル

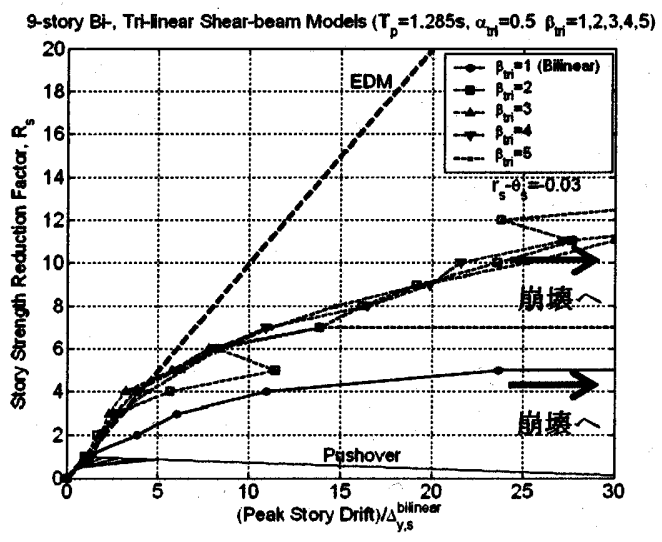

図12多段階降伏ループをもった 9 自由度系せん断棒モデルの最大 層間変形応答

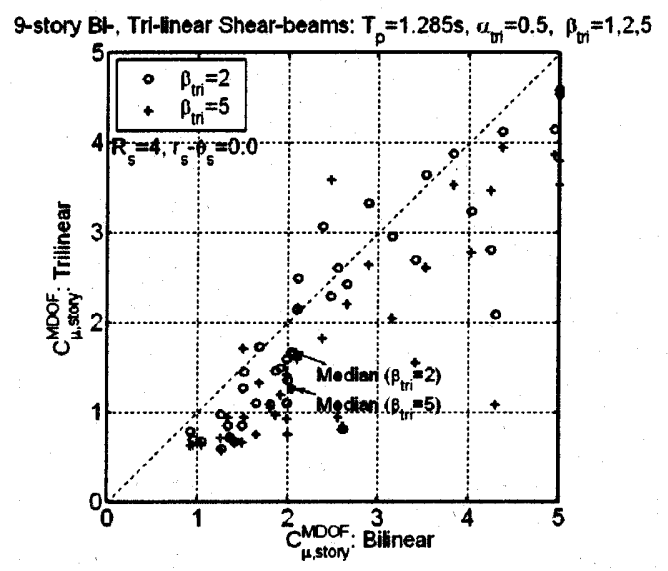

(a) $C_{\mu, s t o r y}{ }^{M D O r}$ for $\left(r_{s}-\theta_{s}\right)=0.0$

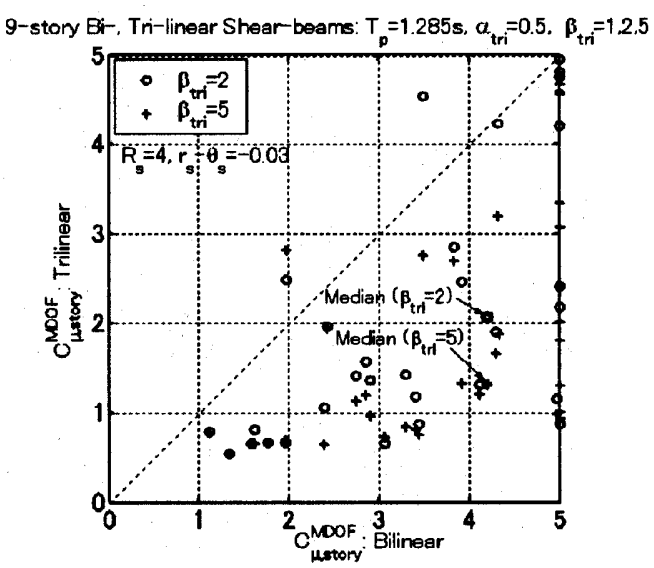

(b) $C_{\mu, \text { story }}{ }^{M D O r}$ for $\left(r_{s}-\theta_{s}\right)=-0.03$

図 139 自由度系 Bilinear、Tri-linear せん断棒モデルの動的応答

表39自由度系モデルにおける多段階降伏効果 $\left(C_{\mu \text { story }}{ }^{M D O P}:\right.$ Median)

\begin{tabular}{|c|c|c|}
\hline$\beta_{\text {trt }}$ & $\left(\mathrm{r}_{\mathrm{s}}-\boldsymbol{\theta}_{\mathrm{s}}\right)=0.00$ & $\left(\mathrm{r}_{\mathrm{s}}-\boldsymbol{\theta}_{\mathrm{s}}\right)=-0.03$ \\
\hline \hline 1 (bilinear) & $2.05(1.08)$ & $4.20(1.18)$ \\
\hline 2 (trilinear) & $1.66(1.02)$ & $2.07(1.08)$ \\
\hline 5 (trilinear) & $1.25(0.93)$ & $1.31(0.91)$ \\
\hline
\end{tabular}




\section{4. 多自由度系混合せん断+曲げ棒モデルの地震時举趵}

\section{1 多自由度系混含せん断+曲げ棒モデル}

3.2 および 3.3 において多自由度系せん断棒モデルである層の履 歷が負勾配に入るとその層の变形量が著しく增加する可能性がある ことが分かった。そこでその変形集中を軽減する 1 つの改善案とし て図 14 に示すように $1 \mathrm{D}$ 多自由度系せん断モデルに建物の高さ方 向に貫く曲げ棒を加え、その曲げ棒の勃果を調べた。せん断棒の各 層の節点と曲げ棒の節点は完全に剛のリンク部材で結ばれておりそ れらの節点の水平変位は同じとする。なお曲げ棒は弾性举動を仮定 し曲げ棒と地表面はピンで接合されているものとする。この $1 \mathrm{D}$ 混 合せん断+曲げ棒モデルは、梁先行降伏型のモーメント骨組の地展 時举動、崩壊メカニズムを良く表す ${ }^{10)}$ 。

この粠造モデルに対する微小時間に於ける增分型の運動方程式 は式(9)で表される。ここで[M]は質量行列式、 [C]は減哀行列式、 $\left[k_{s}\right]$ は式(3)で表されるせん断棒モデルの䣓性行列, $\left[k_{f}\right]$ は曲げ棒の剖性 行列、 $\Delta$ は建物の相対水平変形量で、 $\Delta_{\mathbf{8}}$ は地動の水平变形量を示す。 曲げ棒の剛性行列式 $\left[k_{f}\right]$ は、ここでは、節点での水平变位でのみ表 される必要があるので、拘束条件を考虑した行列式の縮小を行う必 要がある。まず、図 15(b)に表されるはり要素の剛性行列式は、式 (10)で表される。これを重ね合わして、曲げ棒全体の哃性行列式は 変位と回轱角の自由度に分けて式(11)で表される。さらに、図 15(a) 及び図 15(c)に表されるように、曲げ棒の各節点において曲げモー メント $\left\{M_{\text {lotal }}\right\}$ が 0 である条件を用いて、水平变位のみに関する曲 げ棒全体の剖性行列式は式(12)で表される。曲げ棒の剖性行列式は、 全ての項において 0 以外の数となるので、その結果、多自由度系混 合せん断曲げ棒モデルの㣚性行列式は全項において 0 以外の数を持 つ。これは、曲げ棒の存在により各層における履歴举動が他層の履 歴特性の影響を受けることを示す。

各層における曲げ棒の曲げ剛性は式(13)で萐される曲げ㣚性率 $\alpha_{c . c}$ で表しにここで $E I_{n}$ は $i$ 層における曲げ棒の曲げ䣓性、 $H_{i}$ は $i$ 層の 高さ、 $K_{o t}$ は $i$ 層におけるせん断棒の水平㣚性)、本研究では全層にわ たり一定に設定した。固有周期は曲げ棒なしの時に1.285 s に設定し、 せん断棒モデルは IBC(2003) 7)で定められる層せん断力に対して全 層間変形角が一定となるように設計したので、曲げ棒の㣚性が增加 しても固有周期はほとんど增加しなかった。せん断棒モデルの各層 の降伏強度は、強度低減係数 $R_{s}$ が4となるように設定した。

$[M]\{d \ddot{\Delta}\}+[C]\{d \dot{\Delta}\}+\left(\left[K_{s}\right]+\left[K_{f}\right]\right)\{d \Delta\}=-[M]\left\{d \ddot{\Delta}_{g}\right\}$

$$
\left\{\begin{array}{c}
F_{i}^{a} \\
M_{i}^{a} \\
F_{i}^{b} \\
M_{i}^{b}
\end{array}\right\}=\left[K_{i}^{\text {element }}\right]\left\{\begin{array}{c}
\Delta_{i}^{a} \\
\theta_{i}^{a} \\
\Delta_{i}^{b} \\
\theta_{i}^{b}
\end{array}\right\}
$$

$\left\{\begin{array}{c}\left\{F_{\text {total }}\right\} \\ \left\{M_{\text {total }}\right\}\end{array}\right\}=\left[\begin{array}{ll}{\left[K_{\Delta \Delta}\right]} & {\left[K_{\Delta \theta}\right]} \\ {\left[K_{\theta \Delta}\right]} & {\left[K_{\theta \theta}\right]}\end{array}\right]\left\{\begin{array}{l}\left\{\Delta_{\text {total }}\right\} \\ \left\{\theta_{\text {total }}\right\}\end{array}\right\}$

$\left[K_{f}\right]=\left\{F_{\text {total }}\right\} /\left\{\Delta_{\text {total }}\right\}=\left[K_{\Delta \Delta}\right]-\left[K_{\Delta \theta}\right]\left[K_{\theta \theta}\right]^{-1}\left[K_{\theta \Delta}\right]$

$$
\alpha_{c . c .}=\frac{E I_{f i} / H_{i}^{3}}{K_{o i}}
$$

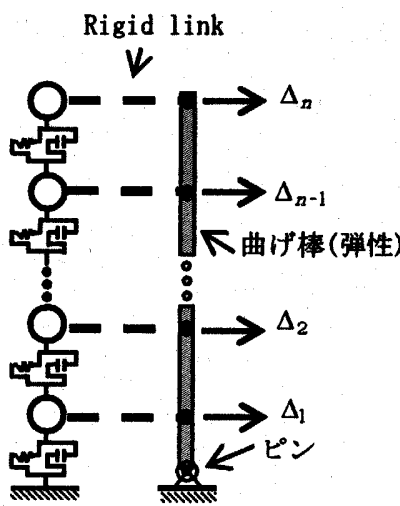

图 14 多自由度系混合せん断+曲げ棒モデル

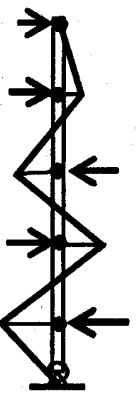

(a)モーメント分布

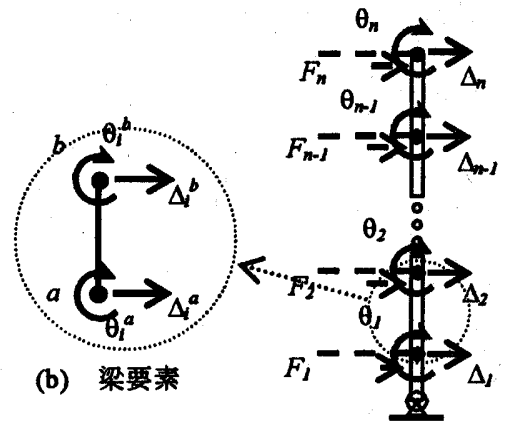

(c) 曲げ棒

図 15 曲げ棒モデルの力学的メカニズム

\section{2 負勾眍の効果}

9自由度系の混合せん断(Bilinear)+曲げ棒モデルにおいて様々の曲 げ棒の曲げ䣓性に対して動的解析を行い層間最大応答変形を求めた。 各層の塑性時の接線㣚性率は一0.03、または-0.06 と設定した。

図 16 に、SAC(1997) $)^{8)}$ の N17 の地展波に対して様々の曲げ棒の 程. に対する各層における層間最大応答変形を示す。ここで曲げ棒 の $\alpha_{c . c .}$ が小さい時は、ある層に変形集中が起こり、塑性時の接線㣚 性率が-0.06 の時、崩壊が起こるのが分かる。しかし、曲げ棒の $\alpha_{c . c .}$ が多少でもあれば、せん断棒モデルの各層における塑性域の負の接 線喇性は、不安定举動や崩壊を引き起こさないことが分かる。つま り、せん断棒モデルの各層にお゙ける負勾配の最大志答に対する影警 は、曲げ棒の曲げ㣚性の効果によって著しく小さくなる。また、曲 げ棒の $\boldsymbol{\alpha}_{\text {r.c. }}$ が上がるに従って建物高さ方向の床最大変位の分布モー ドが図 16(a)中に示すように変わる。

各層せん断バネの塑性域の接線㴊性率が-0.06、曲げ棒の曲げ刚性 率が 0.3 の時の、せん断棒および曲げ棒の 3 階部分における履歷を 図17に示す。ここで、せん断棒の履歴は大きな負勾配をもつが、曲 げ棒からの連成作用により、層全体の履歷の勾配は所々、正に変わ っていることが分かる。この結果は、曲げ棒なしでは不安定挙動を 起こし崩壊していたところが、曲げ棒の存在により特定層への変形 集中が軽減し建物の挙動は安定する現象、所謂、心柱効果、を表し ている。

表 4 に 40 個の SAC(1997) $)^{8)}$ の NF 地震波に対する $C_{\mu, \text { sony }}{ }^{M D O}$ の Median の值を示す。曲げ棒の曲げ剮性が增加するに従って、 $C_{\mu \text { rony }}{ }^{\text {MDOF }}$ の值は、等価な一罂点系モデルに対する $C_{\mu}{ }^{S D O F}$ の值(1.18) に近付いてゆくのが分かる。つまり、曲げ棒の判性を增加させるに 従って、建物モデルの全体举動は 1 自由度系モデルの举動に近づく。 


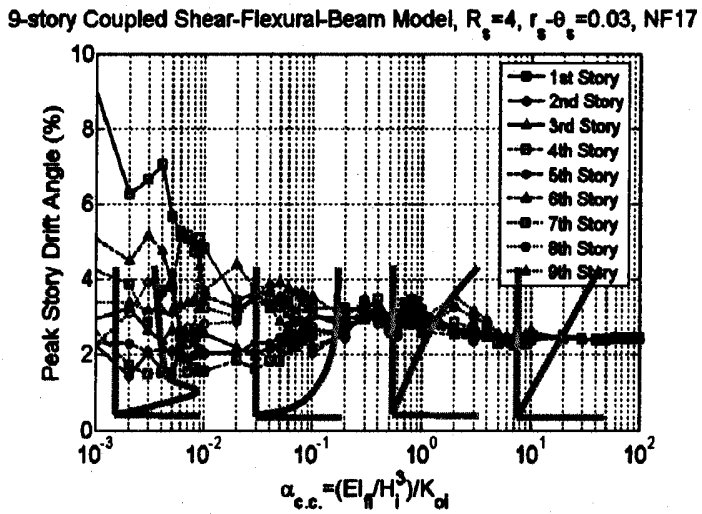

(a) Response for $\left(r_{s}-\theta_{s}\right)=-0.03$

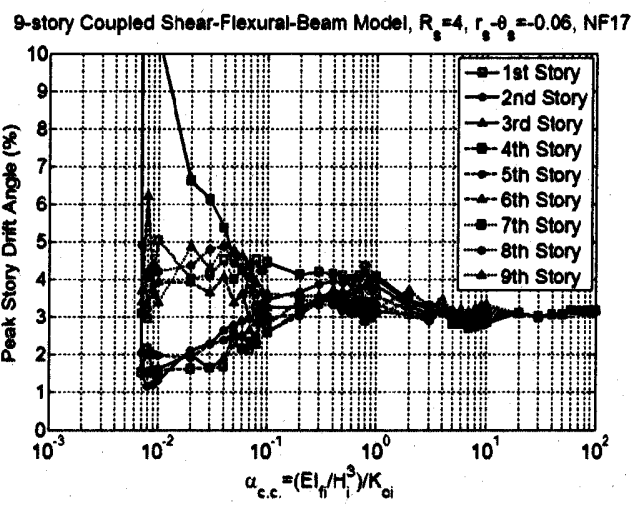

(b) Response for $\left(r_{s}-\theta_{8}\right)=-0.06$

图 169 自由度系混合せん断+曲げ棒モデルの最大層間変形応答

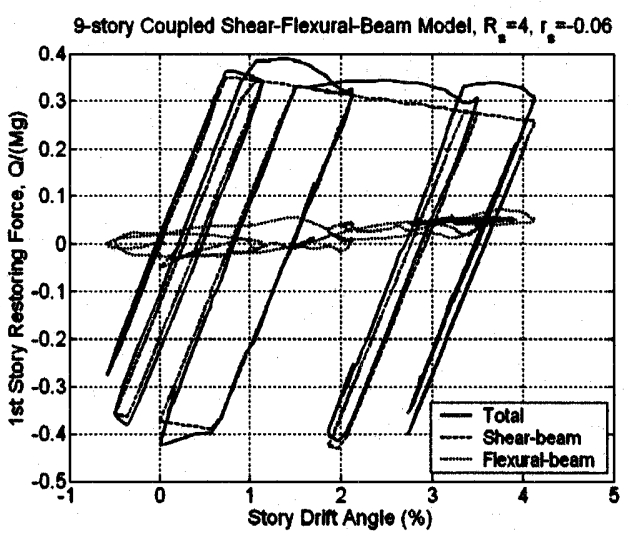

図 17 せん断棒、曲げ棒の 3 階部分における履歴

表49自由度系混合せん断+曲げ棒モデルにおける多段階降伏勃果

\begin{tabular}{|c|c|c|c|}
\hline SDOF & \multicolumn{2}{|c|}{$C_{\mathrm{p}}^{\text {SDOF }}$} & 1.18 \\
\hline \hline \multirow{4}{*}{ MDOF } & & C.C. $=0.0$ & 4.20 \\
\cline { 3 - 4 } & $C_{\mu, \text { Mtory }}^{\text {MDOF }}$ & C.C. $=0.1$ & 1.44 \\
\cline { 3 - 4 } & & C.C. $=0.3$ & 1.32 \\
\hline & & C.C. $=1.0$ & 1.23 \\
\hline
\end{tabular}

\section{3 多段階降伏の効果}

次に $1 \mathrm{D}$ 混合せん断+曲げ棒モデルにおける多段階降伏の奻果を 調べる。多自由度系混合せん断(Tri-linear)+曲げ棒モデルを図 18 に 示す。この研究では、 $\alpha_{t r i}=0.5 、 \beta_{t r i}=1,2,3,4,5$ と仮定し、また、 モデルは9点とし、固有周期を1. $285 \mathrm{~s}$ とした。娌的解析には、同 じく、SAC $(1997)^{8)}$ の断層近傍型の40個の地层波を用いた。Bilinear

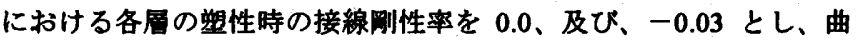
げ棒の $\alpha_{\text {c.c. }}$ を、0.0(純せん断モデル)、0.1、0.3，及び、1.0 とする。

まず、2.2 および 3.3 で行ったように、多自由度系混合せん断+曲 げ棒モデルに対しても様々の地震動強さに対する多段階降伏効果を 評価した。図 19 より各層の強度低減係数 $R_{s}$ が 20 以上になっても Bilinear、Tri-linear 型モデルともに地展動の強さが增加するに従って、 層間最大変形応答も徐々に增加し、ほぼ同じような層間最大変位応 答を示すことが分かる。

次に、元となる Bilinear せん断棒モデルの各層の降伏強度を、強 度低下係数(弾性举動を仮定したときの强度に対する実際の降伏強 度の比)が4となるように設定した。1 D 混合せん断(Bilinear、 Tri-linear)+曲げ棒モデルにおける層間最大応答変形を、層間弾性最 大态答変形で標準化した值の最大值を図 20 で比較する。曲げ棒の $\alpha_{c . c .}$ を 0.3、および 1.0 に、また塑性時の接線剛性率は-0.03に設定し

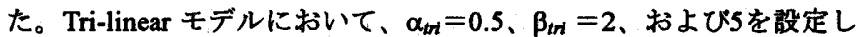
た。図より、的.c.が上がるにつれて、Bilinear モデルと Tri-linear モデ ルは、同じような最大応答変形をもつことが分かる。このことは、 曲げ棒による層間の連成効果により、せん断モデルの各層における 多段階降伏勃果が消失することを意味する。

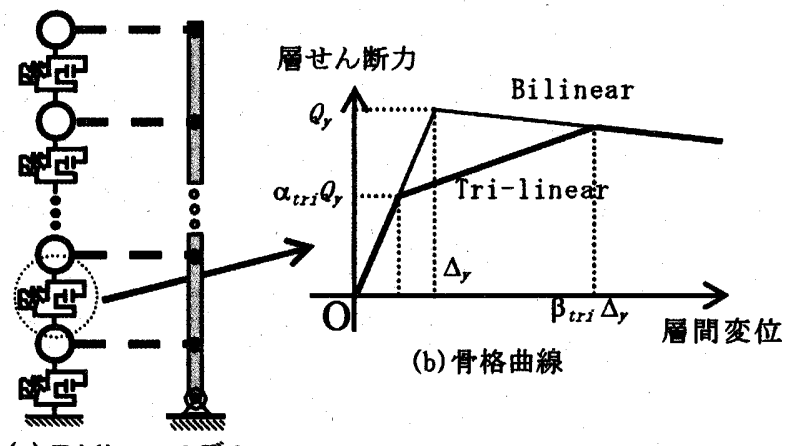

(a) Tri-linear モデル

图181D多自由度系混合せん断(Tri-linear)+曲げ棒モデル 9-story 8t. Tritinear Shear-beam Models with C.C. $\left(T_{p}=1.285 \mathrm{~s}, \alpha_{\mathrm{wi}}=0.5 a_{\mathrm{wi}}=1,2,3,4,5\right)$

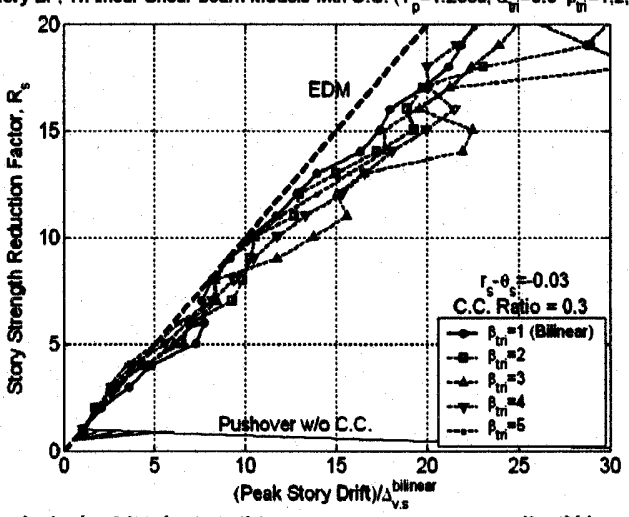

图 199 自由度系混合せん断(Bilinear, Tri-linear)+曲げ棒モデルの最 大層間変形㤁答 


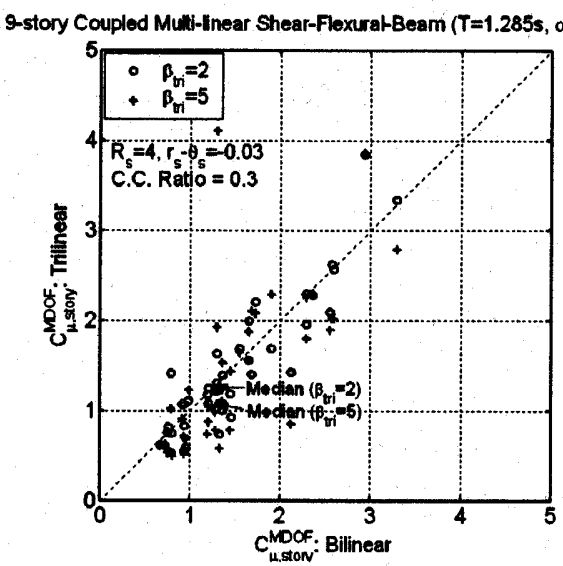

(a) Drift for $\alpha_{c . c .}=0.3$

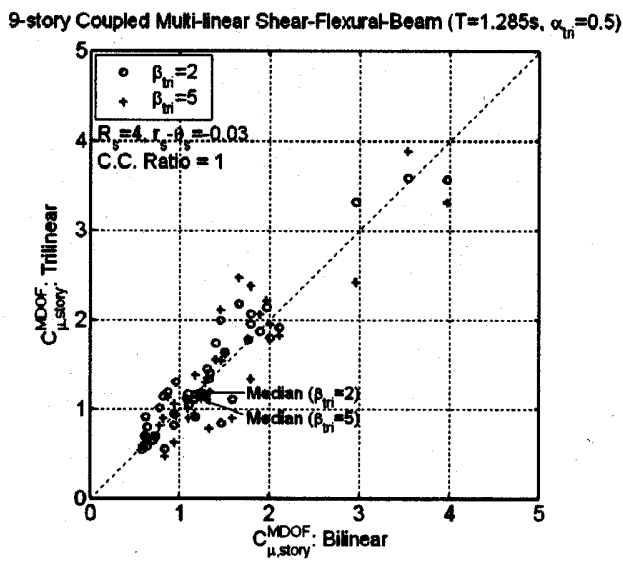

(b) Drift for $\alpha_{c, c .}=1.0$

図 201 D 混合せん断(Bilinear, Tri-linear)+曲げ棒モデルの動的态答

\section{5. 結綸}

本研究では、降伏後の負勾配、ならびに多段階降伏型の履歴をも つ1 自由度、多自由度系モデルを用い、多数の動的非線形解析を行 った。本論文では固有周期が 1.285 秒(鉄骨 9 階建てを想定)を取り上 げたが、0.546秒(3 階建て)、2.229 秒(20階建て)の場合にも同様の結 果が得られた ${ }^{10)}$ 。主な解析結果、結論は以下のようになる。

1 . 1 自由度系モデルでは、降伏後の接線剛性が負になると、最 大态答変形が著しく増大し崩壊する危険性が極めて高くなる。

2. 1 自由度系モデルにおいては、降伏後に負の勾配を持つ Bilinear モデルの履歷曲線を多段階降伏型にかえると一般に 最大応答変形は減少したが、その多段階降伏の効果はあまり 期待できない。

3. 多自由度系せん断棒モデルでは、降伏後の接線敝性が負にな ると層閒最大応答変形が著しく增大し、崩壊する危険性が極 めて高くなる。これは、1自由度系モデルで見られた現象と 同じである。

4. 多自由度系せん断棒モデルにおいて、各層において降伏後に 負勾配をもつ Bilinear モデルの履歴曲線を多段階降伏型にか えると、層閒最大変形は大きく減少した。この多段階降伏の 効果は、1自由度系モデルに対する効果よりも著しく大きい。
5. 多自由度系混合せん断+曲げ棒モデルでは、せん断棒の各層 における降伏後の接線剛性が負になっても、曲げ棒の曲げ剛 性が多少でもあると、層閒最大态答変形はあまり変わらない。 これは、曲げ棒がせん断棒の降伏後の各層における負の接線 剛性を增加させるからである。

6. 多自由度系混合せん断+曲げ棒モデルにおいては、曲げ棒の 存在により、せん断棒の各層にみられた多段階降伏の効果は 消失し、 $C_{\mu, \text { rory }}{ }^{\text {MDO }}$ は、等価な 1 自由度系で推定される $C_{\mu}^{\text {SDO }}$ に近ついてゆく。

本論文中の Bilinear モデルは全ての柱梁接合部が䣓の、Tri-linear モ デルはピン接合を含む鉄骨部分骨組を想定しており、それらの履歷 が建物全体の举動に与える影警について評価している ${ }^{10)}$ 。尚、この 後の展開として、本研究の $1 \mathrm{D}$ 混合せん断+曲げ棒モデルを用いて、

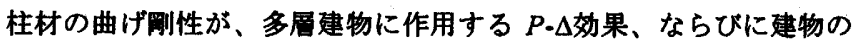
動的安定性に及ぼす影警を数量的に評価する予定である。

\section{辞}

本論文を執箻するに当たり、京都大学教授の渡谴史夫先生、およ び東京工業大学助教授の山田哲先生に贵重なご意見およびご指導を 頂きました。ここに、感謝の意を表します。

\section{类文文嗝}

1) 建築省住宅局建築指導課、同市街地建築䂺、(財)日本建築セン ター編 : 改正建築基準法令集、2000 年 7 月.

2) FEMA: NEHRP Guideline for the Seismic Rehabilitation of Buildings (FEMA356), Washington D.C., 2000.

3) Jennings, P. and Husid, R.: Collapse of Yielding Structures under Earthquakes, Journal of Engineering (Mechanics), ASCE, 94, 1968.

4) MacRae, A. G.: P- $\Delta$ Effects on SDOF Structures in Earthquakes, Earthquake Spectra, Vol. 10, No. 3, 1994.

5）小川厚治、黑羽啓明、待鳥婜治: 劣化域を考虑した鋼構造物の エネルギー吸収能力の評価基準に関する一考察、日本建築学会 構造系論文集、第 492 号、113-119 頁, 1997 年 2 月.

6）小川厚治、黒羽啓明、待鳥筑治: 強辰をうける 1 自由度系の正 負 2 方向の損伤分布に関する研究、日本建策学会楎造系論文集、 第 481 号、117-126 頁, 1996 年 3 月.

7) ICCI: International Building Code, International Conference of Building Officials, Whittier, CA, 2000.

8) Somerville, P. 等: Development of ground motion time histories for phase 2 of the FEMA/SAC steel project, Rep. No. SAC/BD97/04, SAC Joint Venture, Sacramento, California, 1997.

9) Vamvatsikos, D. and Cornell, A.: Incremental Dynamic Analysis, Earthquake Engineering and Structural Dynamics, Vol. 31, 3, 2002.

10）田川浩之: Towards an Understanding of Seismic Performance of 3D Structures - Stability \& Reliability, Doctorate Thesis, University of Washington, Seattle, 2005.

11) FEMA: State of the Art Report on Systems Performance of Steel Moment Frames Subject to Earthquake Ground Shaking, FEMA-355C, 2000. 